\title{
ABRÁZIÓSAN KOPTATOTT FELÜLETEK KIÉRTÉKELÉSE ÉRDESSÉGMÉRÉS SEGÍTSÉGÉVEL A KOPÁS KEZDETI SZAKASZÁBAN
}

\section{EVALUATION OF THE ABRASIVE WEAR PROCESS BY ROUGHNESS MEASURING IN THE CASE OF INITIAL STAGE OF WEAR}

\author{
Barányi István \\ Óbudai Egyetem, Bánki Donát Gépész és Biztonságtechnikai Mérnöki Kar, Gépszer- \\ kezettani és Biztonságtechnikai Intézet, Cím: 1081, Magyarország, Budapest, Nép- \\ színház utca 8.; Telefon / Fax: +36-1-666-5337, baranyi.istvan@bgk.uni-obuda.hu
}

\begin{abstract}
Nowadays one of the most important tasks in tribology to design the surfaces optimised to the operation. According to the literature we can define clearly and detailed all of the optimal machining parameters, but we have only limited information about the changes of surface microtopography. In a case of tribological test researchers define the wear rate and form and identifying the wear form, but the roughness profile modification which defines example the real contact area, the heat and material transport have been investigated only a small degree.

In this article $\mathrm{i}$ would like to introduce the modification of the amplitude roughness parameters in a point of view of normal force and sliding distance in a case of non-lubricated abrasive process.

Keywords: wear, abrasion, average roughness, skewness, kurtosis, peak, valley.

\section{Összefoglalás}

Napjaink egyik legfontosabb kutatói feladata, hogy a gyártott felületek tribológiai szempontból is optimalizálva legyenek a teljes életút során. A szakirodalom alapján elmondhatjuk, hogy a gyártott felületek optimalizálása az utóbbi években egyre szélesebb spektrumot ölel fel, viszont csak korlátozott információink vannak arra vonatkozóan, hogy müködéskor a felületi mikrotopográfia hogyan változik. Tribológiai vizsgálatoknál legtöbbször a kopási formák azonosítása és a kopási intenzitás meghatározása a fó cél, az érdességi profil kiértékelése legtöbbször a háttérbe szorul annak ellenére, hogy az érdesség változása határozza meg például a hő és az anyag transzportot.

Jelen cikkben a szerző az amplitúdótól függő érdességi paraméterek változását mutatja be a felületeket összeszorító erő és a súrlódási úthossz függvényében száraz súrlódás esetén.
\end{abstract}

Kulcsszavak: kopás, abrázió, átlagos érdesség, ferdeség, lapultság, csúcs, völgy.

\section{Bevezetés}

Az utóbbi évtizedekben az érdességmérési és kiértékelési technika jelentős fejlődésen ment keresztül. A mérőmüszerek és kiértékelési technikák fo- lyamatos fejlődése lehetővé tette a gyártott felületek többszempontú kiértékelését [1][2][3][4].

A tribológiai vizsgálatok szempontjából vizsgálva az érdességmérési lehetőségeket 
elmondhatjuk, hogy a szakirodalomnak csak egy szük köre foglalkozik részletesen az érdesség változásával, mivel folyamatos koptatási kísérletben nincs mód a mérés elvégzésére [5] [6]. A szakaszos mérés ellenére a kutatók egyre többször egészítik ki az online kiértékelési eredményeiket érdességmérési adatokkal [7] [8].

A cikkben a kopás kezdeti szakaszának egy érdesség mérés segítségével történő kiértékelési lehetőségét mutatom be a bekopási szakasz különböző stádiumaiban.

\section{Anyag és módszer}

Az érdességmérési szabványok a paramétereket négy csoportra osztják:

- amplitúdó paraméterek;

- térközi paraméterek;

- hibrid paraméterek;

- statisztikai paraméterek.

A mérnöki gyakorlatban széleskörüen alkalmazott amplitúdótól függő paramétereket az (1)-(6) egyenletek definiálják:

$$
\begin{gathered}
R a=\frac{1}{N} \sum_{i=1}^{N}|y(i)| \\
R q=\sqrt{\frac{1}{N} \sum_{i=1}^{N} y(i)^{2}} \\
R v=|\min (y)| \\
R p=|\max (y)| \\
R s k=\frac{1}{N R q^{3}} \sum_{i=1}^{N} y(i)^{3} \\
R k u=\frac{1}{N R q^{4}} \sum_{i=1}^{N} y(i)^{4}
\end{gathered}
$$

Ahol:

- Ra átlagos érdesség;

- $\quad \mathrm{Rq}$ közepes mértani eltérés;
- Rv völgymélység;

- Rp csúcsmagasság;

- Rsk ferdeségi mérőszám;

- Rku lapultsági mérőszám;

- N pontok száma a mérési hosszon;

- y(i) pontok magassági koordinátája.

3. Mérési eredmények ismertetése

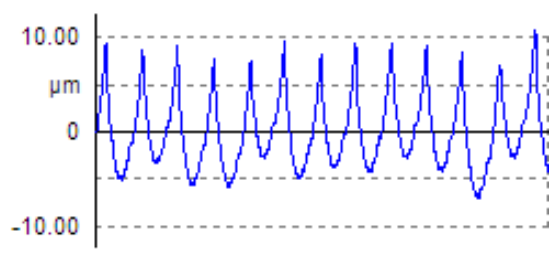

a., kezdeti profil

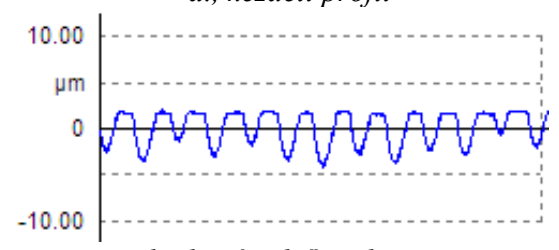

b., kopás elsö szakasza

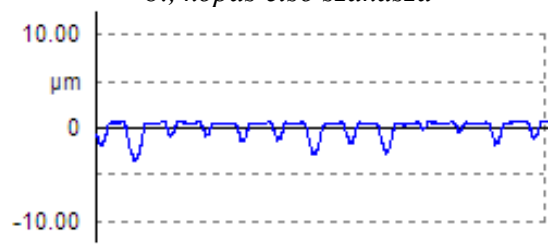

c., kopás második szakasza

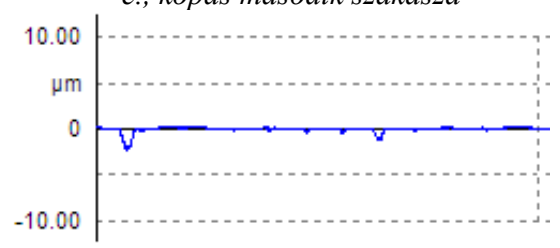

d., kopás harmadik szakasza

1. ábra. A profilok változása a kopás négy szakaszában

A vizsgált próbatestek ütőkéses gyártási technológiával készültek C45-ös normalizált acélból. A gyártáskor alkalmazott előtolás $0,2 \mathrm{~mm}$ volt. A koptatási kísérletnél alkalmazott beállítások: 
- úthossz: $600 \mathrm{~mm}$ és $10800 \mathrm{~mm}$ között változott $600 \mathrm{~mm}$ lépésközzel;

- normálerő: $200 \mathrm{~N}$ és $600 \mathrm{~N}$ között változott $200 \mathrm{~N}$ lépésközzel;

- $\quad$ koptatási sebesség: $25 \mathrm{~mm} / \mathrm{s}$;

- kenési állapot: száraz súrlódás.

A koptatási vizsgálatok közben az érdességi paraméterek értékét Mahr Perthen Concept metszettapintós érdességmérő segítségével határoztuk meg. A mérési hossz $12,5 \mathrm{~mm}$ volt 0,5 mikrométeres lépésközzel.

Az 1. ábrán a kopás során megsemmisült csúcszónák profilmódosító hatását láthatjuk.

A (1)-(6) egyenletek által definiált öszszefüggések által érdességi paraméterek változását a 2 . ábra szemlélteti a felületeket összeszorító normálerő és a koptatási úthossz függvényében.
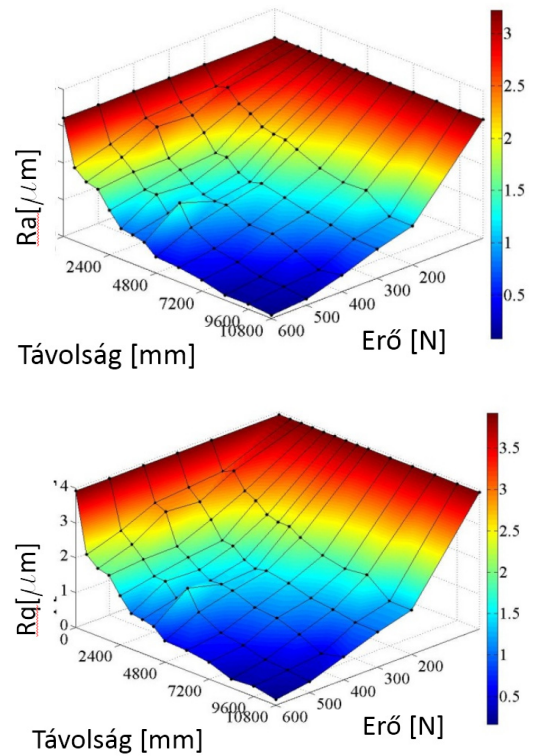
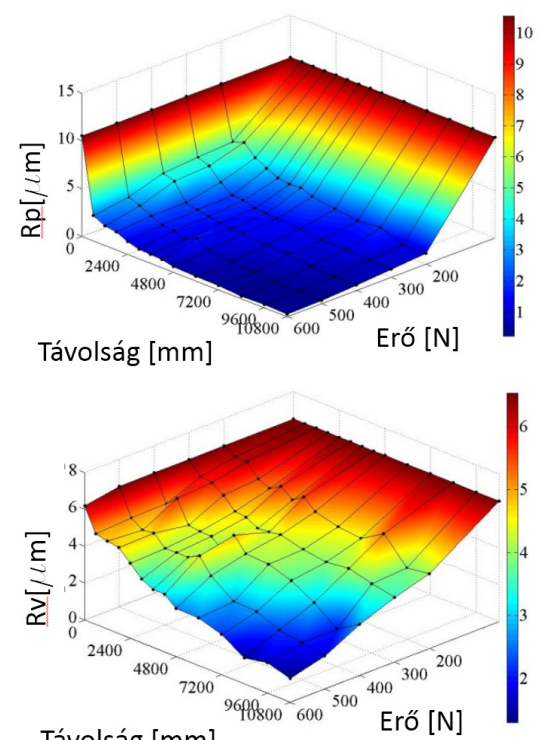

Távolság [mm]
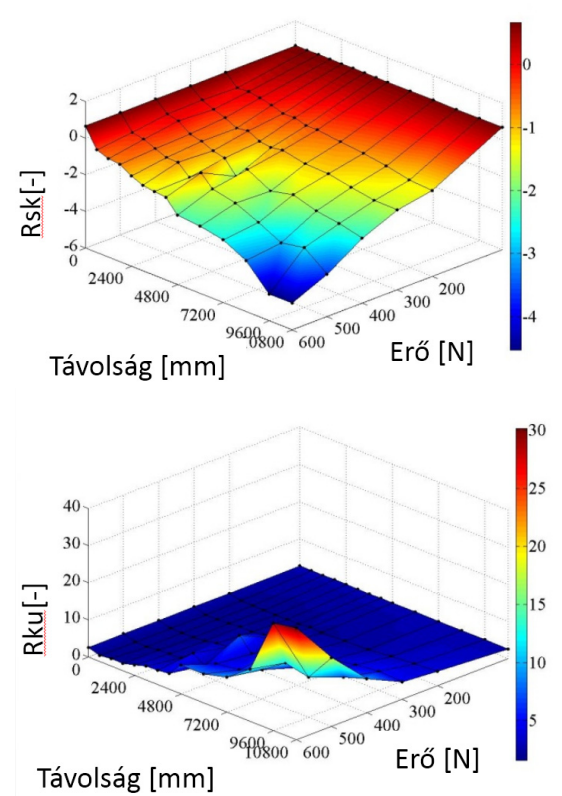

2. ábra. Az érdességi paraméterek változása a kopási folyamat során

\section{Következtetések}

A 2. ábrán látható, hogy az átlagos érdesség és a közepes mértani eltérés az erő és a koptatási úthossz függvényében hasonlóan változik. Ez annak köszönhető, hogy (1) és (2) alapján az Rq értéke bár érzékenyebb a lokális hibákra, de a koptatás során 
a csúcs és völgyzónában nem voltak lokális hibák (az abráziós szemcsék nem módosították a völgyzónát).

A csúcs és a völgyzóna magassága bár minden méréskor csökkent, de a völgyzóna változása lassúbb mértékü, mert a csúcszóna folyamatosan szélesedett az abráziós kopás miatt.

A ferdeségi és a lapultsági mérőszámok a kopási intenzitást jól jellemzik: a folyamatos magzóna megsemmisülés miatt az Rsk értéke folyamatosan csökkent az Rku növekedése mellett. Ez a folyamat annak a hatásnak köszönhetö, hogy a középvonal folyamatos lefelé tolódása mellett lokális hibák nem zavarták meg a mérési eredményeket.

\section{Szakirodalmi hivatkozások}

[1] Kári-Horváth, A., Valasek I.: Machining: some new aspects, R\&D Mechanical Engineering Letters, 2009. 75-87.

[2] Kári-Horváth, A. ; Valasek, I.: Demand of Energy for Chip Detachment, Materials Science, Testing and Informatics, 2010. 489497.

[3] Sipos, S.; Palásti K., B.; Horváth, R. (2010): Environmental-Friendly Cutting of Automoti- ve Parts, Made of Aluminium Castings, Hungarian Journal of Industrial Chemistry 38:(2), 99-105.

[4] Horváth, R.; Palásti K., B.; Sipos, S. (2011): Optimal tool selection for environmentalfriendly turning operation of aluminium, Hungarian Journal of Industrial Chemistry 39(2), 257-263.

[5] Zsidai, L.; De Baets, P.; Samyn, P.; Kalácska, G.; Van Peteghem, A.P.; Van Parys, F. (2002): The tribological behaviour of engineering plastics during sliding friction investigated with small-scale specimens, Wear 253, 673-688.

[6] Rodregues, V.; Sukumaran, J.; Ando, M. (2011): Roughness measurement problems in tribological testing, Sustainable construction \& design 2:(1), 115-121.

[7] Ando, M.; Sukumaran, J. (2012): Effect on Friction for Different Parameters in RollSlip of Polyamide-Steel Nonconformal Contacts, Tribology transactions 55:(1), 109116.

[8] Sukumaran, J.; Ando, M.; Rodregues, V.; De Baets, P.; Neis, P. D.(2011): Friction torque, temperature and roughness in rollslip phenomenon for polymer-steel contacts, Mechanical engineering letters: R\&D: Research \& Development 5, 7-16. 